DOI: https://doi.org/10.32839/2304-5809/2020-6-82-19

UDC 37.015.324.2

Halchak Tetiana

Berezhany Agrotechnical College

\title{
PROFESSIONAL BURNOUT OF TEACHERS
}

Summary. The article reveals the essence and structure of burnout, describes the subjective and objective stressors, symptoms and stages of teachers' burnout, explores ways to prevent the negative effects of emotional burnout. Burnout is one of the most common reasons that teachers are leaving their profession, and it contributes to the increased teacher turnover rate in the past few decades. Teacher burnout is an extreme form of chronic stress that can affect any educator, regardless of how experienced or passionate they are about their jobs. It is hypothesized that prevention of teachers burnout should be based on the idea of psychological means as determined by socio-cultural formative influences of psychotechnical tools. The essence of the burnout syndrome as been revealed as well as modern psychological studies of this phenomenon in teachers.

Keywords: professional burnout, exhaustion, stressful factors, level of responsibility, modern educational system.

Гальчак Т.В.

Бережанський агротехнічний коледж

\section{ПРОФЕСІЙНЕ ВИГОРАННЯ ВЧИТЕЛІВ}

Анотація. У статті розкривається суть та структура професійного вигорання вчителів, описуються суб'єктивні та об’єктивні чинники, що викликають стрес, симптоми та стадії вигорання вчителів, досліджуються способи запобігання негативних наслідків емоційного вигорання. Доводиться гіпотеза про те, що профрілактика професійного вигорання вчителів повинна базуватися на застосуванні психологічних засобів, визначених соціокультурними формувальними впливами психотехнічних інструментів. Розкривається сутність синдрому професійного вигорання та проаналізовано сучасні психологічні дослідження даного феномену. Оскільки, професійне вигорання - це не одномоментний акт, а тривалий процес «згорання дотла", його деструктивний потенціал проявляеться в наступному: зникнення інтересу до роботи, звуження контактів з колегами, зниження якості діяльності, виникнення почуття невпевненості в собі , поява незадоволеності життям. Останне породжує «замкнуте коло», коли у людини відсутня самоповага і здорова самооцінка, вона втрачае впевненість в майбутньому і тим самим сенс життя. Метою дослідження е уточнення симптомів і провокуючих чинників синдрому емоційного вигорання в професійній діяльності педагогів. Як відомо, виникненню синдрому професійного вигорання передує перебування у стресі, у практичній діяльності психолога варто вирішувати питання профілактики стресових розладів, ознайомлювати вчителів із засобами профілактики стресових розладів, стратегіями та методами саморегуляції, самодопомоги. Необхідно проводити консультативну, профілактичну, та, за необхідністю, корекційну роботу з питань управління емоціями, надавати можливості для самостійного оволодіння навичками роботи зі своїм емоційним станом. Психопрофілактична робота з вчителями мае бути спрямована, в основному, на розвиток гнучкості їх поведінки, тобто на різноманітність та адекватність, які проявляються у зовнішніх (рухових) та у внутрішніх (психічних) формах активності. До взаєморозуміння та конструктивної взаємодії учителя і учня може привести бажання вчителя зрозуміти особливості та принципи сприйняття, мислення, переживання учня, що е можливим, коли вчитель сприймає та усвідомлюе себе самого та власні ціннісні оріентири.

Ключові слова: професійне вигорання, виснаження, стресові чинники, рівень відповідальності, сучасна система освіти.

Tntroduction. Professional activity of high 1 school teachers is considered to be one of the most informative and emotional. Scientific and pedagogical activity of teachers involves numerous unpredictable communicative situations, a high level of responsibility, difficulties in determining the effectiveness of their own activities. All this can be a professional stress, which over time reduces the resistance of teachers to psychophysical burnout. Even among some students there are harbingers of emotional burnout - indifference, the dominance of negative emotions, loss of ideals, feelings of helplessness, low levels of emotional stability, etc. [4].

Modern teacher is in a situation of rapid changes in all areas of life, leading to the need for modernization of education. The emergence of new digital, informational, humanitarian, and other technological capabilities that are becoming available to educators require their serious development and implementation. The expansion of channels of interaction with subjects of education focuses on the use of virtual relationships that complement real ones and need constant support.

Generation gap and transformation of the teacher put him in a search situation, which leads to a permanent refinement of the strategy and tactics of promoting and solving professional problems. Improving the effectiveness of this process largely depends on the pace and quality of development of various external and internal resources used by the teacher. The need for teacher's active participation in all these changes leads to a sharp intensification of pedagogical activity, communication and relations, the implementation of which increases the demand for their own professional and personal resources.

In this paper the following research problems are addressed: 
P1: Examine the factors which contribute to educator burnout.

P2: Replenishing professional and personal emotional resources of a teacher.

Literature review. Burnout is seen as a special mental state of a person that is a consequence of occupational stress. Recently, occupational burnout has been included in the International Classification of Diseases. Therefore, it becomes important to study the causes of occupational burnout, its diagnosis and prevention.

In 1974, Herbert Freudenberger became the first researcher to publish in a psychology-related journal a paper that used the term "burnout." $\mathrm{He}$ characterized burnout by a set of symptoms that includes exhaustion resulting from work's excessive demands as well as physical symptoms such as headaches and sleeplessness, "quickness to anger," and closed thinking. He observed that the burnedout worker "looks, acts, and seems depressed." After the publication of Freudenberger's original paper, interest in occupational burnout grew.

Burnout is a response to the prolonged exposure to occupational stress which negatively affects the individuals, the organisations, and the healthcare service recipients (Maslach \& Leiter, 2008).

Now we encounter various definitions of burnout. Burnout (combustion, extinction) is considered a special human condition that is a consequence of occupational stress. Occupational burnout is a syndrome that develops against the background of chronic stress, which leads to depletion of emotional, energy and personal resources of the teacher. Occupational burnout is a long-term stress response or syndrome that occurs as a result of prolonged uncontrolled occupational stress of medium intensity [5; 7].

Based on the theory of American scientists S. Jackson and K. Maslach, occupational burnout is considered a three-dimensional system. The structure of this phenomenon consists of emotional exhaustion, depersonalization and reduction of professional achievements [2]. Exhaustion, in their opinion, is manifested in excessive emotional saturation or indifference and a reduced level of emotional background. The teacher focuses on the work process, refuses to meet non-work needs. Exhaustion is manifested in overexertion, fatigue, exhaustion of internal resources. After rest, the forms of burnout become less intense, but resume immediately after returning to work.

Methods. The conceptual and methodological model of empirical research of psychological means of professional burnout prevention is based on the idea of the organic relationship of psychological means as "internal" resources-techniques and as "external" signs-tools. The selected set of psychodiagnostic methods aimed to identify accurately the prevalence and intensity of the phenomenon "professional burnout" of teachers in general, this dependent variable was determined using the method of diagnosing the level of emotional burnout by V. Boyko.

The level of the independent variable was determined by the questionnaire "Strategy for overcoming stressful situations" by S. Hobfall. The system of other - intermediate - variables was formed by the resources of personal and professional develop- ment of teacher in the form of internal prerequisites for self-actualization of the individual - in order to identify the eponymous questionnaire E. Shostrom; individual-typological differences as accentuations of the corresponding character traits and temperament - G. Shmishek's questionnaire; types of personality orientation - the questionnaire of the same name by V. Smeykal and M. Kuchera, harmony or conflict of the self-concept - the method of "Q-sorting" by V. Stephenson. The differentiated effect of additional variables was also taken into account, which were socio-demographic and professional-qualifying determinants of professional burnout (age, gender, marital status, having their own children, specialty, level of qualification, general and pedagogical work experience) and side variables, which are due to the action of subjective perception of the studied conditions of the experimental situation - used a questionnaire to assess working conditions and professionally important traits of the teacher. The application of the method of diagnosing the level of emotional burnout V. Boyko allowed to diagnose the structural and dynamic indicators of teachers' professional burnout.

Research results. Depersonalization is a state of alienation from oneself, inadequate perception of one's ego. Traced in the deformation of social contacts, the emergence of dependence on them, or the manifestation of negativism in relation to the social environment, to themselves, personal detachment (negative feelings towards colleagues, students, themselves). This leads to indifference, reduction of professional achievements, ie the process of reducing complex work to simple. This is reduced professional productivity: a negative attitude to their own professional achievements, the emergence of feelings of incompetence in their professional activities, awareness of failure in it, loss of sense of efficiency, disbelief in their own capabilities and professional growth, reduced job satisfaction.

The objective factors that cause professional burnout of the teacher include: 1) chronic intense psycho-emotional activity, which is associated with intense and long-term communication; 2) destabilizing organization of activity, high level of workload, constant contradictions in management, lack of objective criteria for work evaluation, inefficient system of motivation and stimulation of teachers, ambiguity of work requirements, monotony of performed functions, authoritarian management style, abuse of power, threats to management, etc.); 3) increased responsibility for the functions and operations performed, in particular for the quality of education and well-being of students; 4) unfavorable psychological atmosphere of professional activity.

Burnout arises not only from stressful objective factors, but also from the way teacher treats them, how he evaluates them. Each teacher responds to the same loads in their own way.

Teachers with the following personal characteristics are most prone to burnout: high meticulousness, demonstrativeness, high ability to empathize, pessimism, emotional instability, tendency to anxiety and depression or aggression, a sense of excessive responsibility, obligation for the task, high level of self-control, excessive anxiety, worry, vulnerability, sensitivity and condemnation, significant energy loses, excessive positive attitude to 
the performance of professional duties, inconsistency of the knowledge level and skills to professional requirements, introversion, chronic fear of losing a job, etc.

Stress is attributed to the primary cause of emotional burnout arising in pedagogical and medical activities with limited internal resources related to the purpose and quality of professional work, and it has also been established that "increasing stress resistance and mastering self-regulation skills: relaxation, ideomotor acts, meditation contributes to effective burnout" and etc.".

Psychological prevention of professional deformities is based on the formation of self-efficacy, self-confidence, the ability to correctly calculate their resources and replenish them in a timely manner, the skills of adequate assessment of the results of their own activities (reflection).

It should be noted that in the process of psycho-correctional work with teachers, attention should be focused not on the state of helplessness and weakness, but on the development of axiological and acmeological potentials and the formation of internal resources of adaptive energy.

Modern educational system requires from the teacher a quick response to daily events, the accuracy of his actions and the proper level of formation of his emotional sphere. The teacher as a subject of educational process has an impact on the individual through the prism of the formation of its own relevant and holistic sphere, so if he is prone to emo- tional burnout, he needs not only psychotherapeutic help, but also the acquisition of constructive skills of self-regulation of subjective personal sphere.

Conclusions. Emotional burnout syndrome of teachers, as a state of personality that arises in the process of professional activity, is a complex process of orientation of the individual in their own intra-individual space, which contains psycho-constitutional features and subjective-personal attitude to professional activity, which is manifested in violation of personal self-identification, merging with environmental influences on the basis of emotional involvement.

Thus, professional burnout is a process of gradual reduction of the level of efficiency of the physical, cognitive and emotional spheres of a person. The structure of professional burnout includes emotional exhaustion, depersonalization and reduction of professional achievements. Identifying their own style of responding to stress, expanding behavioral repertoire, developing skills of constructive interaction, work on changing the installation, the use of stress relief techniques and more may be appropriate actions to prevent burnout.

Promising areas of psychological and pedagogical research on the problem of "professional burnout" are the deepening of theoretical ideas about "professional burnout" of specialists in various fields, improving psychotechnologies to prevent and overcome this syndrome, taking into account the specifics of professional activity.

\section{References:}

1. A.B. Bakker, L.L. ten Brummelhuis, J.T. Prins, F.M.M.A. van der Heijden (2011). Applying the job demands Resources model to the work-home interface: A study among medical residents and their partners. Journal of Vocational Behavior, no. 79, pp. 170-180.

2. Byrne, B.M. (1994). Testing for the factorial validity, replication, and invariance of a measuring instrument: A paradigmatic application based on the Maslach Burnout Inventory. Multivariate Behavioral Research, no. 29, pp. 289-311.

3. Demerouti, E., Bakker, A.B., Vardakou, I., \& Kantas, A. (2003). The convergent validity of two burnout instruments. A multitrait-multimethod analysis. European Journal of Psychological Assessment, no. 19, pp. $296-307$.

4. Gold, Y., Roth, R.A., Wright, C.R., Michael, W.B., \& Chin-Yi, C. (1992). The factorial validity of a teacher burnout measure (Educators Survey) administered to a sample of beginning teachers in elementary and secondary schools in California. Educational and Psychological Measurement, no. 52, pp. 761-768.

5. Hakanen, J.J., Schaufeli, W.B., \& Ahola, K. (2008). The job demands-resources model: A three-year cross-lagged study of burnout, depression, commitment, and work engagement Work \& Stress. An International Journal of Work, Health \& Organisations, no. 22, pp. 224-241.

6. Kelloway, E.K. (1995). Structural equation modeling in perspective. Journal of Organizational Behavior, no. 16, pp. 215-224.

7. Maslach, C., \& Leiter, M. (2008). Early predictors of job burnout and engagement. Journal of Applied Psychology, no. 93 , pp. 498-512.

8. Nahrgang, J.D., Morgeson, F.P., \& Hofmann, D.A. (2011). Safety at work: A meta-analytic investigation of the link between job demands, job resources, burnout, engagement, and safety outcomes. Journal of Applied Psychology, no. 96, pp. 71-94.

9. Orel, V.E. (2005). Sindrom psikhicheskoho vyhoraniia lichnosti [Syndrome of mental burnout of a person]. Yaroslavl: Institut psikholohii RAN Publ., 330 p. (in Russian)

10. Poghosyan, L., Aiken, L.H., \& Sloane, D.M. Factor structure of the Maslach Burnout Inventory: An analysis of data from large scale cross-sectional surveys of nurses from eight countries. 